14. „On amendments to the Tax Code of Ukraine and some legislative acts of Ukraine to ensure the balance of budget revenues in 2016”. The Law of Ukraine. The Verkhovna Rada of Ukraine, zakon5.rada.gov.ua/laws/show/909-19. Accessed 10 Nov. 2020.

15. Skyba, L. „Revenues of local budgets in ensuring the powers of local governments”. Ukrainian science: past, present, future, no.17, 2012, pp.128-133.

16. Slatvinska, M. „Local taxes and fees: positive and negative aspects of implemented innovations”. Economic and social development of Ukraine in the XXI century: national vision and challenges in globalization: coll. thesis add. XII International. scientific-practical conf. young scientists. TNEU, 2015, pp. 204-205, dspace.tneu.edu.ua/bitstream/316497/5882/1/СЛАТВІНСЬКА\%20М.pdf. Accessed 10 Nov. 2020.

УДК 330.101:620.91-027.236

doi: 10.15330/apred.1.16.122-133

\title{
Климчук М.М., Климчук С.А. РОЗРОБКА МЕХАНІЗМУ ФОРМУВАННЯ РЕГІОНАЛЬНОЇ СИСТЕМИ УПРАВЛІННЯ ЕНЕРГОЗБЕРЕЖЕННЯМ НА ЗАСАДАХ ДОСВІДУ КРАЇН СВРОПЕЙСЬКОГО СОЮЗУ
}

\author{
Київський національний університет \\ будівництва і архітектури, \\ Міністерство освіти і науки України, \\ кафедра організації та управління \\ будівництвом, \\ проспект Повітрофлотський, 31, Київ, \\ 03680,Україна, \\ тел.:0663398973, \\ e-mail: klimarinchuk@gmail.com
}

\begin{abstract}
Анотація. У статті досліджено теоретичні аспекти розробки та реалізації енергоефективної політики регіонів, виокремлено основні напрями іiі впровадження. Розглянуто основні інструменти стимулювання енергозбереження в країнах $\mathrm{CC}$.

Проаналізовано діючі міжнародні проєкти розвитку регіональної енергоефективної політики та підтримки підприємств, що впроваджують заходи енергозбереження в країнах Європейського Союзу. Наведено елементи системи оцінювання результатів проєкту за критеріями: розвиток smart-технології, упровадження фінансових інструментів, міжрегіональна співпраця, стратегії інтелектуальної спеціалізації. 3 метою забезпечення фінансовими ресурсами проєктів енергозбереження та енергоефективності нами надані пропозиції щодо використання муніципальних облігацій та компенсаторної технології «Тах Increment Financing».

За результатами вивчення світових тенденцій управління енергозбереженням на рівні регіону, нами запропоновано механізм формування регіональної системи управління енергозбереженням, як певну сукупність принципів, цілей, завдань, функцій, суб'єктів, процесу з урахуванням наявних потреб й можливостей реалізації заходів енергозбереження.

В рамках упровадження механізму формування регіональної системи управління енергозбереженням надано характеристику цілям (економічні; соціальні; екологічні); завданням (організаційні; інституційні; інфраструктурні; інвестиційні; інноваційні; соціальноекономічні; екологічні; інформаційні); принципам (раціонального використання ресурсів; наукового обгрунтування управління; державно-приватного партнерства; адаптації та мобільності); суб'єктам, функціям та інструментам управління.

Ключові слова: енергозбереження, управління, регіональна політика, міжнародний досвід.
\end{abstract}




\title{
Klymchuk M.M., Klymchuk S.A. DEVELOPMENT OF THE MECHANISM OF FORMATION OF THE REGIONAL SYSTEM OF ENERGY SAVING MANAGEMENT ON THE BASIS OF EXPERIENCE OF THE COUNTRIES OF THE EUROPEAN UNION
}

\author{
Kyiv National University \\ Engineering and Architecture, \\ Ministry of Education and Science of Ukraine, \\ Department of organization and construction \\ management, \\ ave Povitroflotsky 31, Kyiv, \\ 03680, Ukraine, \\ tel.: 0663398973, \\ e-mail: klimarinchuk@gmail.com
}

\begin{abstract}
The article examines the theoretical aspects of development and implementation of energy efficiency policy of the regions, highlights the main directions of its implementation. The main tools for stimulating energy saving in the EU countries are considered. The current international projects for the development of regional energy efficiency policy and support for enterprises implementing energy saving measures in the European Union are analyzed. The constituent elements of the project evaluation system according to the criteria are formed: development of smarttechnology, introduction of financial instruments, interregional cooperation, strategies of intellectual specialization.

In order to provide financial resources for energy saving and energy efficiency projects, we have provided proposals for the use of municipal bonds and compensatory technology "Tax Increment Financing". Based on the results of studying global trends in energy management at the regional level, we proposed a mechanism for forming a regional energy management system, as a set of principles, goals, objectives, functions, entities, process, taking into account existing needs and opportunities for energy saving measures.

Within the framework of introduction of the mechanism of formation of the regional system of management of energy saving the characteristic of the purposes (economic; social; ecological) is given; tasks (organizational; institutional; infrastructural; investment; innovation; socio-economic; environmental; information); principles (rational use of resources; scientific substantiation of management; public-private partnership; adaptation and mobility); entities, functions and management tools.
\end{abstract}

Key words: energy saving, management, regional policy, international experience.

Вступ. Питання розробки та реалізації енергоефективної політики регіонів $\epsilon$ актуальними для всіх розвинених країн світу, незалежно від їхнього державного устрою та рівня економічного розвитку. Основні напрями реалізації регіональної політики у сфері енергозбереження, а також механізми та інструменти ії проведення мають певну специфіку для кожної країни, що обумовлено енергоємністю ВВП, потенціалом альтернативних джерел енергії, наявної регіональної стратегії імплементації заходів енергозбереження, рівнем впровадження енергоефективних інновацій на підприємствах [4-5].

Для України загалом і для кожного іï регіону зокрема, проблематика активізації процесів енергозбереження обумовлена суттєвою енергомісткістю національної економіки. Значні міжрегіональні диспропорції у формуванні й реалізації енергоефективних заходів в будівництві, визначає доцільність розвитку теоретичних і прикладних засад управління енергозбереженням, як у форматі регіоналізації, так і на рівні виробничо-економічної системи. Проте, значна централізація, недостатність 
фінансових ресурсів не надають можливість місцевій владі ідентифікувати напрями диверсифікації ресурсів на реалізацію регіональної політики енергозбереження.

КМУ схвалив «Концепцію впровадження механізмів стабільного фінансування заходів з енергоефективності (створення Фонду енергоефективності)», у якій зазначено, що обсяг щорічного споживання природного газу для опалення в Україні оцінюється у 18,6 млрд. куб. метрів (річна оцінка споживання газу проведена з урахуванням помірної температури в опалювальний сезон). При цьому потенціал скорочення щорічного споживання природного газу для опалення в Україні у разі досягнення поточного рівня втрат в СС становить 11,4 млрд куб. метрів газу (60 \% імпорту України): теплова санація будинків - 7,3 млрд куб. метрів газу, заміна індивідуальних котлів - 1,7 млрд куб. метрів газу, модернізація котелень - 1,1 млрд куб. метрів газу, модернізація мереж - 1,3 млрд куб. метрів газу. Показник питомого енергоспоживання в Україні значно вищий ніж відповідний показник у країнах ЄС. Зокрема, середнє питоме енергоспоживання у багатоквартирних житлових будинках становить 264 кВт॰год/кв. метр, тоді як у європейських країнах відповідний показник в середньому не перевищує 90 кВт•год/ кв. метр [7].

Вивчення питань впровадження енергоефективної політики в розрізі регіону займались вітчизняні учені: М. О. Кизим, Т. І. Салашенко, Л. С. Сімків, В. В. Шпілєвський, П. В. Писаренко, М. С. Самойлік, О. Ю.Диченко, О. М. Руденко [1; 6; 8].

Важливі економічні фактори формування ефективної регіональної політики у своїх працях досліджували британські вчені, такі як Недлеман (Needleman, 1965), Томас і Сторі (Thomas i Storey, 1971), Браун (Brown, 1972), Садлер, Арчер, Оуен (Sadler, Archer, Owen, 1973) [16].

Деякі країни 3 метою подолання незбалансованості в соціально-економічному розвитку регіонів вжили заходи, щоб надати підтримку менш успішним регіонам. У своїх працях $[12 ; 15 ; 16]$ вчені наводять приклад цілої системи засобів контролю, яка спрямована на обмеження інвестицій в регіони, які вже досить розвинені. Її реалізація передбачає подальше узгодження цілей загальнонаціонального планування i регіональної економічної політики.

У сучасних умовах розвитку вченими пропонується впровадження механізмів державного управління завдяки системі стимулів, переваг і механізмів фінансування програм, пов’язаних з енергозбереженням та енергоефективністю. Однак, практично без уваги залишається дослідження питань розробки механізму формування регіональної системи управління енергозбереженням 3 урахуванням досвіду Європейських країн.

Постановка завдання. Мета статті полягає в розробці механізму формування регіональної системи управління енергозбереженням 3 урахуванням досвіду Європейських країн.

Результати. Розглянемо основні інструменти політики стимулювання енергозбереження в СС. У червні 2012 року прийнята Директива СС з енергетичної ефективності (Директива СC 2012/27/EU), яка визначає загальний комплекс заходів 3 підвищення рівня енергоефективності та містить наступні положення:

- реконструкція будівель - країни-члени ЕС мають проводити реконструкцію як мінімум 3 \% площі будівель, що опалюються, які займають органи державної влади;

- збільшення ефективності енергетичних систем;

- проведення енергоаудиту;

- підвищення рівня ефективності систем опалення та кондиціювання повітря;

- розробка механізмів фінансування [11].

На основі даних сайту Свропейської Комісії Кеер.еu нами проаналізовано діючі міжнародні проєкти розвитку регіональної енергоефективної політики та підтримки 
підприємств, що впроваджують заходи енергозбереження. Keеp.eu обслуговує всю професійну аудиторію, яка потребує зведених даних щодо проектів та бенефіціарів програм транскордонного, транснаціонального та міжрегіонального співробітництва Європейського Союзу.

Розглянемо основні проекти у сфері розвитку регіональної політики на засадах енергоефективності, енергозбереження, які впроваджуються на території Європейського Союзу (табл. 1).

Таблиия 1

\section{Характеристика основних просктів підтримки розвитку регіонів Свропейського Союзу}

\section{Table 1}

Characteristics of the main projects to support the development of the regions of the European Union

\begin{tabular}{|c|c|}
\hline $\begin{array}{c}\text { Назва проекту та загальний } \\
\text { бюджет } \\
\end{array}$ & Сутність \\
\hline $\begin{array}{l}\text { Smart Clusters for Smart } \\
\text { Growth through Joint Business } \\
\text { Intelligence (4 Smart Growth) } \\
\text { Загальний бюджет проєкту - } \\
\text { EUR } 1063833.33\end{array}$ & $\begin{array}{l}\text { Проект 4SmartGrowth впроваджуються в п’яти регіонах-партнерів та } \\
\text { спрямований на розширення можливостей підприємницької діяльності } \\
\text { за рахунок впровадження в роботу smart-технологій. Такий підхід } \\
\text { базується на взаємній довірі та співпраці між партнерами та кластерами, } \\
\text { які вони представляють. Проєктна група формулює стратегічні } \\
\text { пріоритети для підприємств певного сегменту ринку, а також проводить } \\
\text { тренінги, воркшопи, семінари } 3 \text { метою підтримки бізнесу на рівні } \\
\text { регіону. }\end{array}$ \\
\hline $\begin{array}{l}\text { Cross-border Cooperation and } \\
\text { Competitiveness for SMEs } \\
\text { (ЗС4SME). } \\
\text { Загальний бюджет проєкту - } \\
\text { EUR } 597555.00\end{array}$ & $\begin{array}{l}\text { Проєкт спрямований на підтримку малих та середніх підприємств в } \\
\text { регіонах Албанії та Чорногорії. } 3 \text { метою підвищення } \\
\text { конкурентоспроможності регіону та подолання низки перешкод, що } \\
\text { виникають в процесі виробничо-комерційної діяльності пропонується } \\
\text { впроваджувати фінансові кооперативи, які нададуть можливість } \\
\text { створити надійну фінансову базу для розвитку. У багатьох випадках це } \\
\text { єдині офіційні фінансові організації, які сприяють стабілізації } \\
\text { фінансової системи під час криз. Проблему, яку має вирішити проєкт, } \\
\text { посилення економічного зростання на визначених територіях за } \\
\text { допомогою інструменту фінансових кооперативів. }\end{array}$ \\
\hline $\begin{array}{l}\text { Access to Microfinance for } \\
\text { Small and Medium-sized } \\
\text { Enterprises (ATM for SMEs). } \\
\text { Загальний бюджет проєкту - } \\
\text { EUR } 1639836.00\end{array}$ & 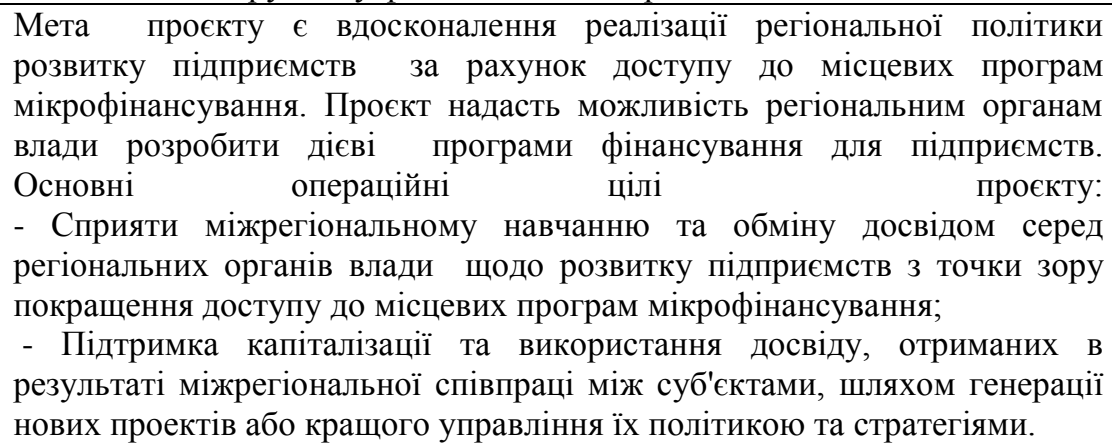 \\
\hline $\begin{array}{l}\text { Baltic Entrepreneurship } \\
\text { Laboratories (BELT). } \\
\text { Загальний бюджет проєкту - } \\
\text { EUR } 1101851.32\end{array}$ & $\begin{array}{l}\text { Концепція розвитку розумного міста спрямована на пошук інтегрованих } \\
\text { рішень проблем сталого розвитку, що потребують інноваційних форм } \\
\text { співпраці та більш інтегрованої підтримки бізнесу. BЕLT фокусується на } \\
\text { розвитку спільних та ефективних бізнес-можливостей на основі } \\
\text { концепції «Smart сіtу», яке є пріоритетом СC у сфері регіональної } \\
\text { політики для підтримки міжгалузевих «розумних інновацій». BELT } \\
\text { сприяє створенню стартапів на рівні університетів регіону } 3 \text { метою } \\
\text { залучення талановитих студентів орієнтованих на підприємництво. } \\
\text { Сприяє формуванню серед партнерів спільний мережі ВоotСатрs } 3 \\
\text { метою комерціалізації бізнес-ідей. }\end{array}$ \\
\hline $\begin{array}{l}\text { Stimulating smart specialization } \\
\text { ecosystem through engaging } \\
\text { SMEs in open innovation }\end{array}$ & $\begin{array}{l}\text { Основною метою є підвищення компетенції та можливостей суб'єктів } \\
\text { інноваційної діяльності щодо застосування транснаціонального підходу } \\
\text { до реалізації своїх регіональних та національних стратегій розумної }\end{array}$ \\
\hline
\end{tabular}




\begin{tabular}{|c|c|}
\hline $\begin{array}{l}\text { processes ( BSR Stars S3) } \\
\text { Загальний бюджет проєкту - } \\
\text { EUR } 2895192.19\end{array}$ & $\begin{array}{l}\text { спеціалізації. Проект фокусується на міжгалузевій співпраці на основі б } \\
\text { циркулярної } \quad \text { та цифрової економік, що } 3 \text { метою формування та } \\
\text { впровадження } \text { стратегій інтелектуальної спеціалізації в регіонах Сконе } \\
\text { (Швеція), Копенгагену (Данія), Тампере (Фінляндія), Вільнюса (Литва)). }\end{array}$ \\
\hline $\begin{array}{l}\text { Boost regional } \\
\text { Entrepreneurship by Enabling } \\
\text { cross border cooperation } \\
\text { Загальний бюджет проєкту - } \\
\text { EUR } 565685.76\end{array}$ & $\begin{array}{l}3 \text { метою покращення ситуації на засадах партнерства мі } \\
\text { інформаційним центром Rietavas, муніципалітетом округу Тало } \\
\text { кластером зелених та розумних технологій та Клайпедським державни } \\
\text { університетом прикладних наук реалізують проект «Посиленњ } \\
\text { регіонального підприємництва шляхом сприяння транскордонном } \\
\text { співробітництву», яка має на меті сприяти підприємництву } \\
\text { муніципалітетах. }\end{array}$ \\
\hline
\end{tabular}

Сформовано на основі [14].

Проаналізувавши низку проєктів у сфері енергоефективності, цифровізації, «smart інновацій», що впроваджуються на території країн Європейського Союзу можна виокремити наступні інструменти розвитку регіональної політики, які б доцільно використати і в регіонах нашої країни:

- Формування кластерів на засадах зеленої економіки 3 метою поширення використання відновлювальних джерел енергії та впровадження smart- технологій;

- Створення коучингових мереж, розвиток потенціалу старапів та проектних інкубаторів у сфері енергоефективності;

- Бізнес-школа для молоді з метою виявити їх здібності, надати базові компетенції для успішної самореалізації у майбутньому та допомогти впровадити власні комерційні , соціальні та екологічні проекти;

- Залучення інвестицій бізнесу у науково-дослідні проекти;

- Розвиток співпраці між підприємствами, науково-дослідними центрами та закладами вищої освіти 3 метою трансферу технологій, впровадженню соціальних та екоінновацій;

- Підтримка технологічних та прикладних досліджень у сфері енергоефективності, вдосконалення виробничих можливостей виробництва.

- Упровадження послуг для розвитку та просування підприємництва в регіоні, формування креативної, інформаційної інфраструктури підтримки бізнесу;

- Ініціація переходу від використання державних коштів на інновації до залучення краудфандингу та краудсорсингу для фінансування.

3 метою забезпечення фінансовими ресурсами проєктів енергозбереження та енергоефективності пропонуємо використання муніципальних облігацій та компенсаторної технології «Тах Increment Financing», у своїх дослідженнях [2-4; 9] нами доведено ефективність такого інструментарію, особливо в рамках енергокластера регіону.

Управління енергозбереженням - це самостійна система, для якої характерні складність, багатофункціональність, багатоаспектність. Управління такими складними об’єктами має здійснюватися у рамках системного підходу. Енергозбереження, таким чином, розглядається у контексті єдності та взаємозв'язків його складових компонент.

Застосування системного підходу в управлінні енергозбереженням на рівні регіону - це можливість оцінити вплив негативних факторів й ризиків в процесі управління елементами регіональної системи енергоефективності, а також розробити раціональний комплекс організаційно-інституційних рішень, прийнятних як для складових компонентів, так і для всієї регіональної системи в цілому.

Як показує проведене дослідження впровадження проєктів потребує цілісної, ефективної системи оцінювання їх результатів за визначеними критеріями (табл.1). 
Таблиия 1

\section{Складові елементи системи оцінювання результатів проскту за визначеними критеріями}

Table 1

Components of the project results evaluation system according to certain criteria

\begin{tabular}{|c|c|c|c|c|}
\hline \multirow[t]{2}{*}{ Назва проєкту } & \multicolumn{4}{|c|}{ Базисні критерії оцінювання результатів проєкту } \\
\hline & $\begin{array}{c}\text { Розвиток } \\
\text { smart-технології }\end{array}$ & $\begin{array}{c}\text { Впровадження } \\
\text { фінансових } \\
\text { інструментів }\end{array}$ & $\begin{array}{c}\text { Міжрегіональна } \\
\text { співпраця } \\
\text { (інтеграційні } \\
\text { формування) }\end{array}$ & $\begin{array}{c}\text { Стратегії } \\
\text { інтелектуальної } \\
\text { спеціалізації }\end{array}$ \\
\hline $\begin{array}{c}\text { Smart Clusters for } \\
\text { Smart Growth through } \\
\text { Joint Business } \\
\text { Intelligence (4 Smart } \\
\text { Growth) }\end{array}$ & $\checkmark$ & & $\checkmark$ & $\checkmark$ \\
\hline $\begin{array}{l}\text { Cross-border } \\
\text { Cooperation and } \\
\text { Competitiveness for } \\
\text { SMEs (3C4SME) }\end{array}$ & & $\checkmark$ & & $\checkmark$ \\
\hline $\begin{array}{c}\text { Access to } \\
\text { Microfinance for } \\
\text { Small and Medium- } \\
\text { sized Enterprises } \\
\text { (ATM for SMEs) }\end{array}$ & & $\checkmark$ & $\checkmark$ & \\
\hline $\begin{array}{c}\text { Baltic } \\
\text { Entrepreneurship } \\
\text { Laboratories (BELT) }\end{array}$ & $\checkmark$ & & $\checkmark$ & \\
\hline $\begin{array}{l}\text { Stimulating smart } \\
\text { specialization } \\
\text { ecosystem through } \\
\text { engaging SMEs in } \\
\text { open innovation } \\
\text { processes ( BSR Stars } \\
\text { S3) }\end{array}$ & $\checkmark$ & & $\checkmark$ & $\checkmark$ \\
\hline $\begin{array}{c}\text { Boost regional } \\
\text { Entrepreneurship by } \\
\text { Enabling cross border } \\
\text { cooperation } \\
\end{array}$ & $\checkmark$ & & $\checkmark$ & $\checkmark$ \\
\hline
\end{tabular}

Сформовано на основі [14].

Дієвою системою управління енергозбереженням може бути визначена шляхом вивчення чинників зовнішнього і внутрішнього середовищ об'єкту управління й специфіки заходів енергозбереження. При створенні системи управління енергозбереженням доцільно вирішити такі завдання [4; 8]:

- сформувати організаційну структуру управління;

- підвищити оперативність і дієвість системи управління шляхом створення безпосереднього зв'язку між органами управління i учасниками проектів енергозбереження;

- налагодити взаємодію співвиконавців енергозберігаючої діяльності, що тягне за собою необхідність узгодження цілей учасників енергозбереження, внесення коректив в цільові установки;

- підвищити відповідальність органів управління i кожного конкретного виконавця за результати, терміни виконання заходів й проектів енергозбереження. 
Зацікавленість фахівців в сфері регіонального управління енергозбереженням та науковців зосереджена на низці проблем й питань: - забезпечення взаємоузгодження стратегічних орієнтирів розвитку програм енергозбереження й проведених трансформацій на державному та регіональному рівнях;

- створення умов для ефективної взаємодії рівнів влади у вирішенні проблем реалізації заходів енергозбереження;

- визначення основних векторів регіональної інвестиційної політики; - використання методів ефективного регіонального управління енергозбереженням; - удосконалення регіональної системи управління енергозбереженням.

Важливим вектором вирішення зазначених проблем є забезпечення умов для збалансованості між практичними та теоретичними аспектами регіонального управління енергозбереженням. Рішення даних проблем потребує формування певної регіональної системи управління енергозбереженням.

Під регіональною системою управління енергозбереженням пропонуємо розуміти певний комплекс структурних елементів, у тому числі суб'єкти управління (органи регіональної державної влади), об'єкти управління (регіональні процеси енергозбереження), взаємопов'язані методи, інструменти, що утворюють різного роду підсистеми i опосередковують економічний механізм мотивації реалізації заходів енергозбереження; функціонуючі для підвищення рівня конкурентоспроможності, енергоефективності, енергобезпеки регіону й поліпшення якості життя населення [2-4; 9].

За результатами вивчення світових тенденцій управління енергозбереженням на рівні регіону, нами запропоновано механізм формування регіональної системи управління енергозбереженням, як певну сукупність принципів, цілей, завдань, функцій, суб'єктів, процесу з урахуванням наявних потреб й можливостей реалізації заходів енергозбереження (рис. 1):

Елементами механізму формування регіональної системи управління енергозбереженням, доцільно запропонувати (рис. 1):

- цілі: (економічні (підвищення рівня енергоефективності регіону; зниження сукупних суспільних витрат на виконання основних господарських функцій регіону в результаті зменшення енергетичних витрат; енергоефективне розміщення об'єктів виробництва); соціальні (підвищення рівня і якості життя населення у результаті зниження витрат регіонального бюджету на енергопостачання, витрат населення на комунальні послуги); екологічні (зниження техногенного впливу на навколишнє середовище; покращення екології регіону).

- завдання (організаційні; інституційні; інфраструктурні; інвестиційні; інноваційні; соціально-економічні; екологічні; інформаційні);

- принципи (раціонального використання ресурсів; наукового обгрунтування управління; державно-приватного партнерства; адаптації та мобільності);

- суб'єкти управління (регіональні та муніципальні органи влади; виробники та постачальники енергетичних ресурсів; підприємства; населення; науково-дослідні установи; житлово-комунальні господарства; державні кредитні установи (банки));

- функції управління (цілепокладання - загальна складова функцій управління у реалізації проектів енергозбереження, комбінує всі елементи системи; координація - це узгодження дій всіх керівних ланок на рівні регіону в процесі управління енергозбереженням; контроль - це процес забезпечення досягнення результатів управлінських рішень у контексті реалізації енергоефективних заходів); 


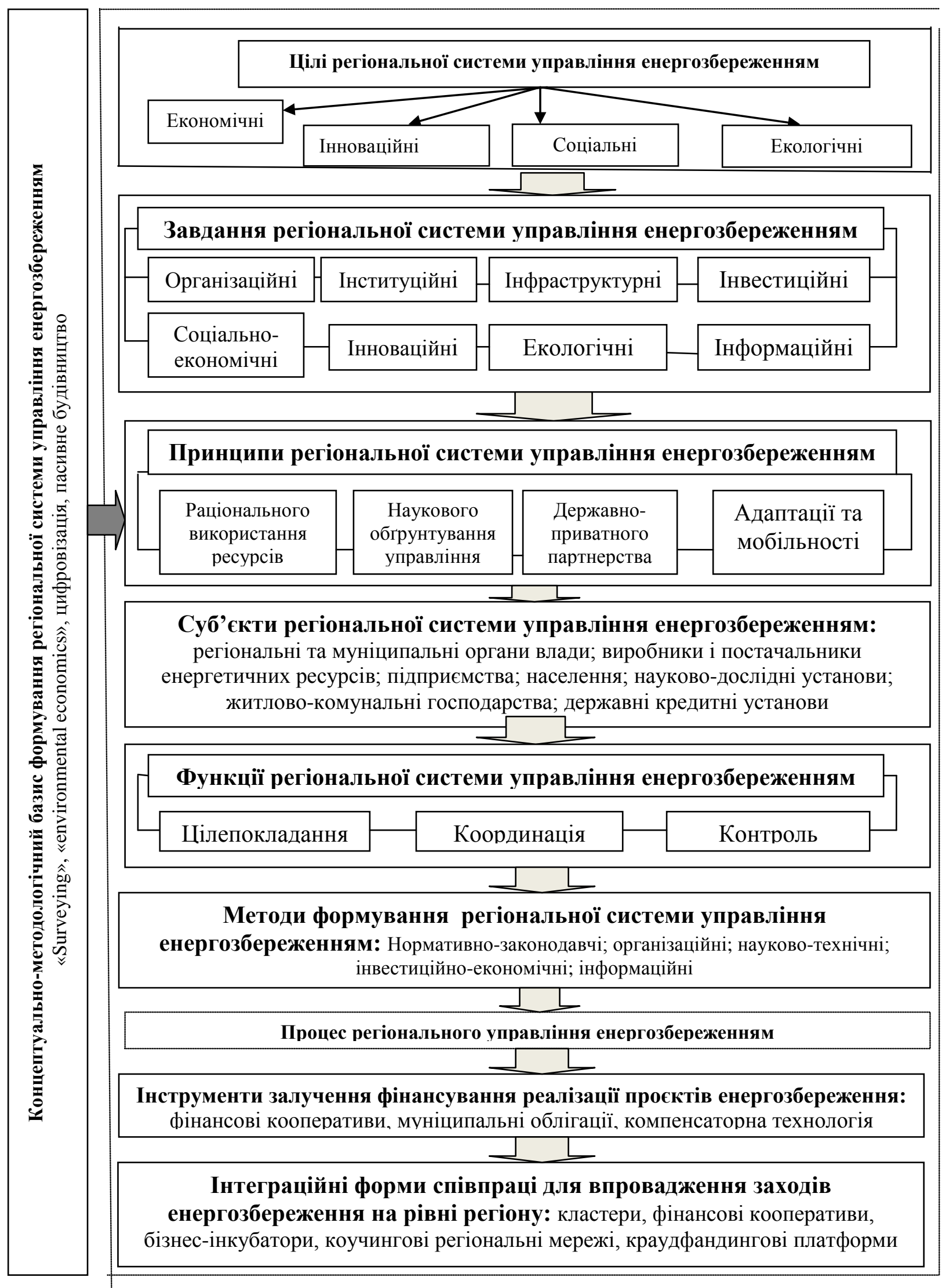

Рuc. 1. Механізм формування регіональної системи управління енергозбереженням (Авторська розробка)

Fig. 1. The mechanism of formation of the regional energy saving management system 
- інструменти управління ((нормативно-законодавчі: закони, постанови, держвні будівельні норми, правила, стандарти, сертифікати), (організаційні: проектування, контроль, облік, регулювання, обстеження, розробка та реалізація;), (науково-технічні: науково-дослідницькі та конструкторські розробки), (інвестиційно-економічні: ціни та тарифи, режим оподаткування, амортизаційний режим, субсидії, гранти, позики, спеціальні фонди), (інформаційні: бази даних, каталоги, навчальні програми, публікації, конкурси та конференції)).

- процес регіонального управління енергозбереженням - це цілеспрямований та керований процес трансформацій у сфері енергозбереження, спрямований на досягнення високого рівня якості життя на території регіону, через реалізацію заходів енергоефективності, використання регіонального потенціалу відновлювальної енергетики.

Ідентифікуючи завдання механізму формування регіональної системи управління енергозбереженням, пропонуємо їх структурувати за такими підгрупами:

1. Організаційні завдання:

- Моніторинг поточної ситуації щодо регіональних програм управління енергоефективністю та енергозбереженням, визначення заходів щодо реалізації запланованих завдань відповідно основних векторів регіонального розвитку та реалізації енергозберігаючих заходів;

- Формування базисних організаційно-економічних детермінант ефективного функціонування регіональної системи енергоефективності та енергозбереження;

- Розробка стратегічних орієнтирів політики енергозбереження регіону в рамках загальнодержавних програм;

- У контексті стратегічних пріоритетів енергозбереження створення служби енергоменеджменту на підприємствах регіону основними завданнями яких є розробка енергопаспортів і програм енергозбереження, адже інформація від підприємств не аналізується та не є джерелом прогнозування та керування енерговиробництвом i енергоспоживанням.

2. Інституційні завдання:

- Формування базисних інституційних детермінант ефективного функціонування регіональної системи управління енергозбереженням;

- Координування проведених інституціональних змін структурної перебудови регіональної економіки в ракурсі енергозберігаючих заходів;

- Створення центрів енергоефективності, що проводитимуть енергоаудит місцевих підприємств, визначаючи резерви економії енергоносіїв i розробляючи пропозиції щодо енергозберігаючих заходів і проектів у регіоні.

3. Інфраструктурні завдання:

- Розвиток умов і формування сприятливого середовища для розширення відтворення основних ресурсів, реалізації внутрішнього потенціалу регіону;

- Забезпечення й сприяння в створенні різних інфраструктурних елементів регіонального господарства - інформаційно-комунікаційної технології, комунальної, транспортної, інженерної, енергетичної, ринкової, фінансової і т.д.;

- Сприяння формуванню фінансових, страхових, консалтингових, маркетингових, аудиторських регіональних ринків у сфері енергозбереження.

4. Інвестиційні завдання:

- Створення сприятливого інвестиційного клімату для суб'єктів господарювання 3 метою впровадження проєктів енергозбереження;

- Реалізація державних пріоритетів інвестиційного розвитку регіону (в тому числі використання методів державно-приватного партнерства); 
- На рівні підприємств і територій розробка та впровадження комплексних методик аналізу еколого-економічної ефективності інвестування в енергозберігаючі проєкти і програми. Це надасть можливість на рівні керівників підприємств і місцевих органів влади сформувати бачення кінцевого результату 3 окремих заходів енергозбереження;

- Створення позабюджетного загальнодержавного фонду енергозбереження як ключового елементу механізму перерозподілу коштів на користь процесу інвестування енергоефективних проєктів та програм. Основна частина накопичуваних фінансових ресурсів даного фонду буде надаватися як пільгові кредити. При цьому розмір пільгової відсоткової ставки встановлюватиметься залежно від енергозберігаючого ефекту проєкту.

5. Інноваційні завдання доцільно реалізувати в контексті:

- Упровадження автоматизованої системи комерційного обліку електричної енергії та встановлення новітніх приладів диференційного обліку енергоресурсів;

- Постійний моніторинг ринку технологій, аналіз маркетингової інформації наявності автоматизованих систем управління виробництвом, що надасть можливість отримувати в реальному часі аналіз споживання енергетичних ресурсів і на цій основі управляти витратами;

- Інфраструктурне забезпечення інновацій в енергозбереження.

6. Соціально-економічні завдання:

- Використання при реалізації енергозберігаючих програм економічного інструментарію у вигляді лізингових схем, грантів, субсидій, що створює основу для їх здійснення;

- Фінансування підприємствами енергоресурсозберігаючих проектів, сприяння трансферу технологій та енергоінновацій;

- Упровадження регламентованої системи у сфері стандартизації, сертифікації та маркування в енергетиці;

- Зниження тарифів на комунальні послуги та підвищення рівня якості життя для населення регіону через впровадження заходів енергоефективності. У результаті проведеної політики енергозбереження зменшуються витрати населення на сплату комунальних тарифів, що сприяє непрямому приросту їх доходів.

7. Екологічні завдання:

- Створення умов для забезпечення екологічної безпеки та захисту природи в регіон;

- Розповсюдження інформації про енергозбереження і його еколого-економічних ефектах серед місцевих органів влади, промислових підприємств, населення;

- Через зменшення обсягу викидів забруднюючих речовин від стаціонарних джерел значно знижується техногенне навантаження на довкілля.

8. Інформаційні завдання:

- Створення консультаційних центрів для населення і юридичних осіб щодо питань ефективності використання енергоносіїв та формування на цій базі ініціативних груп з енергоефективності та енергозбереження 3 широким залученням представників місцевих управлінських структур, неурядових організацій й громадськості;

- Активізація в суспільстві інформаційно-просвітницької роботи в сфері енергозбереження;

- 3 метою залучення інвестицій проведення виставок новітнього енергозберігаючого обладнання;

- Видання інформаційних бюлетенів із рекомендаціями 3 питань енергозбереження для населення, підприємств і організацій; 
- Демонстрація енергоефективних пілотних проектів 3 навчанням місцевого персоналу та розповсюдженням їх знань на реалізацію нових об'єктів будівництва (реконструкції) на території реалізації аналогічних пілотних проектів.

Отже, на сучасному етапі регіонами реалізуються не всі із запропонованих груп завдань впровадження енергозбереження комплексно і системно. На практиці регіонального управління енергозбереженням зазвичай спостерігаються відмінності в підходах, принципах, методах, інструментах, термінах реалізації тих чи інших груп завдань.

Висновки. Проаналізовано діючі міжнародні проєкти розвитку регіональної енергоефективної політики та підтримки підприємств, що впроваджують заходи енергозбереження в країнах Свропейського Союзу. Наведено елементи системи оцінювання результатів проєкту за критеріями: розвиток smart-технології, упровадження фінансових інструментів, міжрегіональна співпраця, стратегії інтелектуальної спеціалізації. 3 метою забезпечення фінансовими ресурсами проєктів енергозбереження та енергоефективності нами надані пропозиції щодо використання муніципальних облігацій та компенсаторної технології «Тах Increment Financing».

Проведений теоретичний аналіз проблематики управління енергозбереженням на рівні регіону надав можливість зробити висновки про те що реалізуються не всі виокремлені завдання, а саме: впровадження енергозбереження на засадах системності, оскільки існують відмінності в підходах, принципах, методах, інструментах, термінах реалізації тих чи інших енергоефективних проєктів.

За результатами вивчення світових тенденцій управління енергозбереженням на рівні регіону, нами запропоновано механізм формування регіональної системи управління енергозбереженням, як певну сукупність принципів, цілей, завдань, функцій, суб'єктів, процесу з урахуванням наявних потреб й можливостей реалізації заходів енергозбереження.

1. Кизим М. О., Шпілєвський В. В., Салашенко Т. І., Борщ Л. М. Ідентифікація національної моделі енергетичної безпеки України: системні складові та пріоритетні напрями. Бізнесінформ. №6. 2016. С. $79-89$.

2. Климчук М. М. Управління фінансуванням енергозбереження на будівельних підприємствах: міжнародний досвід. Бізнес Інформ. 2016. №2. С. 65-70.

3. Климчук М. М. Міжнародний досвід управління фінансуванням проектів енергозбереження. /Міжнародна науково-технічна конференція: «Ефективні технології в будівництві». Київ. 2016. C.80-81.

4. Климчук М. М. Формування регіональної системи енергозбереженням. Соціально-економічний розвиток регіонів в контексті міжнародної інтеграџії: наук . журнал. №.19 (5). 2016. С.17-21.

5. Куліков П.М., Климчук М. М. Управління енергозбереженням на будівельних підприємствах: теорія, методологія, практика : моногр. Івано-Франківськ, вид-во «Фоліант», 2017. 344 с.

6. Писаренко П. В., Самойлік М. С., Диченко О. Ю., Руденко О. М. Оптимізація організаційної структури управління ресурсно-екологічною безпекою на регіональному рівні на інноваційних засадах. Бізнес-інформ. №8. 2020. С. $60-68$.

7. Розпорядження Кабінету Міністрів України від 13.07.2016 «Про схвалення Концепції впровадження механізмів стабільного фінансування заходів 3 енергоефективності» № 489-р. ULR: http://www.kmu.gov.ua/control/uk/cardnpd?docid=249189954 (дата звернення: 10.11.2020 p.)

8. Сімків Л. Є. Стратегічні пріоритети регіональної економічної політики в контексті детермінант економічного зростання. Бізнес-інформ. №3. 2019. С. $96-101$.

9. Ткаченко В.В., Климчук М.М., Клочко А.А. Формування ефективної регіональної політики на засадах цифровізації. Регіональна політика: політико-правові засади, урбаністика, просторове планування, архітектура [зб. наук. пр.]. Київ-Тернопіль : «Бескиди», 2019. Ч. 1. С.29-33.

10. Armstrong H., Taylor J. Regional Economics and Policy. New York: Harvester Wheatsheaf, 1993.

11. Directive 2012/27/EU of the European Parliament and of the Council of 25 October 2012 on energy efficiency, amending Directives 2009/125/EC and 2010/30/EU and repealing Directives 2004/8/EC 
and 2006/32/EC Text with EEA relevance.- Special edition in Croatian: Chapter 12 Volume 004 P. $202-257$

12. Doyle F. Regional policy and European integration, op. cit.,1989.

13. Public Policy and Regional Economic Development, op. cit. Hansen N.(ed.), 1978.

14. Projects and documents. ULR: https://keep.eu/projects/ (дата звернення: 10.11.2020р.)

15. Temple M. Regional Economics, MacMillan Press, Basingstoke, 1994.

16. Vanhove N. Regional policy: A European approach. Aldershote etc.: Ashgate, 1999.

\section{References}

1. Kyzym, M., Shpilevsky, V., Salashenko, T., and L. Borshch. "Identification of the national model of energy security of Ukraine: system components and priority areas.” Business-inform, no.6, 2016, pp. 79 - 89.

2. Klimchuk, M. "Management of energy saving financing in construction companies: international experience.” Business Inform, no.2, 2016, pp. 65-70.

3. Klymchuk, M. "International experience in managing the financing of energy saving projects." International scientific and technical conference"Effective technologies in construction". Kyiv, 2016, pp.80-81.

4. Klymchuk, M. "Formation of the regional system of energy saving." Socio-economic development of regions in the context of international integration: science. magazine, no. 19 (5), 2016, pp.17-21.

5. Kulikov, P., and M. Klymchuk. Energy saving management at construction enterprises: theory, methodology, practice: monograph. Ivano-Frankivsk, Foliant Publishing House, 2017.

6. Pisarenko, P., Samoilik, M., Dychenko, O., and O.Rudenko. "Optimization of the organizational structure of resource and environmental safety management at the regional level on an innovative basis.” Business-inform, no.8, 2020, pp. 60 - 68.

7. "Order of the Cabinet of Ministers of Ukraine dated 13.07.2016 "On approval of the Concept of implementation of mechanisms for stable financing of energy efficiency measures" № 489-r.” www.kmu.gov.ua/control/uk/cardnpd?docid=249189954 Accessed 10 Nov. 2020.

8. Simkiv, L. "Strategic priorities of regional economic policy in the context of determinants of economic growth.” Business-inform, no. 3, 2019, pp. 96 - 101.

9. Tkachenko, V., Klymchuk, M., and A.Klochko. "Formation of effective regional policy on the basis of digitalization.” Regional policy: political and legal principles, urban planning, spatial planning, architecture. Part 1. Kyiv - Ternopil, Beskydy, 2019, pp.29-33.

10.Armstrong H., Taylor J. Regional Economics and Policy. New York, Harvester Wheatsheaf, 1993.

11.Directive 2012/27/EU of the European Parliament and of the Council of 25 October 2012 on energy efficiency, amending Directives 2009/125/EC and 2010/30/EU and repealing Directives 2004/8/EC and 2006/32/EC Text with EEA relevance.- Special edition in Croatian: Chapter 12 Volume 004 P. $202-257$.

12. Doyle, F. Regional policy and European integration, op. cit. (1989),

13.Hansen, N, editor. Public Policy and Regional Economic Development, 1978.

14.Projects and documents. keep.eu, keep.eu/projects/ Accessed 10 Nov. 2020.

15.Temple, M. Regional Economics. MacMillan Press, Basingstoke, 1994.

16.Vanhove, N. Regional policy: A European approach. Aldershote etc., Ashgate, 1999.

УДК 338.24:332.13(477)(043.5)

doi: 10.15330/apred.1.16.133-145

\section{Родченко В. Б. ${ }^{1}, \Pi_{\text {рус Ю. I. }}{ }^{2}$ СТРАТЕГІЧНІ ПРІОРИТЕТИ ПРОСТОРОВО-ЕКОНОМІЧНОГО РОЗВИТКУ РЕГІОНІВ УКРАЇНИ}

${ }^{1}$ Харківський національний університет імені В. Н. Каразіна, НHI «Каразінська школа бізнесу», кафедра управління та адміністрування, майдан Свободи, 4, м. Харків, 61022, Україна, 